\title{
Significant chick loss after early fast ice breakup at a high-latitude emperor penguin colony
}

\author{
ANNIE E. SCHMIDT (1) and GRANT BALLARD \\ Point Blue Conservation Science, 3820 Cypress Drive, \#11 Petaluma, CA 94954, USA \\ aschmidt@pointblue.org
}

\begin{abstract}
Emperor penguins require stable fast ice, sea ice anchored to land or ice shelves, on which to lay eggs and raise chicks. As the climate warms, changes in sea ice are expected to lead to substantial declines at many emperor penguin colonies. The most southerly colonies have been predicted to remain buffered from the direct impacts of warming for much longer. Here, we report on the unusually early breakup of fast ice at one of the two southernmost emperor penguin colonies, Cape Crozier ( $\left.77.5^{\circ} \mathrm{S}\right)$, in 2018 , an event that may have resulted in a substantial loss of chicks from the colony. Fast ice dynamics can be highly variable and dependent on local conditions, but earlier fast ice breakup, influenced by increasing wind speed, as well as higher surface air temperatures, is a likely outcome of climate change. What we observed at Cape Crozier in 2018 highlights the vulnerability of this species to untimely storm events and could be an early sign that even this high-latitude colony is not immune to the effects of warming. Long-term monitoring will be key to understanding this species' response to climate change and altered sea ice dynamics.
\end{abstract}

Received 3 April 2019, accepted 19 November 2019

Key words: Cape Crozier, climate change, sea ice

\section{Introduction}

Emperor penguins (Aptenodytes forsteri, Gray) depend on stable fast ice to breed successfully (with a few exceptions of historically land-based colonies) (Wienecke 2010). As the climate warms, sea ice thickness and extent are expected to decrease, negatively impacting many emperor penguin colonies, particularly those at latitudes north of $70^{\circ} \mathrm{S}$ (Barbraud \& Weimerskirch 2001, Jenouvrier et al. 2009, 2012, 2014, Ainley et al. 2010). Model predictions indicate that more southerly habitats should remain suitable for much longer (Ainley et al. 2010, Jenouvrier et al. 2014).

The emperor penguin colony at Cape Crozier is the first known breeding location for the species, and was first discovered in 1902 (Scott 1905). It is one of the southernmost emperor penguin colonies, with only one known colony located at higher latitude (Gould Bay in the Weddell Sea, $77.7^{\circ} \mathrm{S}$ ) (Fretwell et al. 2012). It is one of only a few emperor colonies that are regularly monitored, with chick counts spanning several decades. We have observed the emperor colony every year since 1996, with formal counts of chicks conducted annually since 2001, complementing surveys conducted by Kooyman and colleagues (Barber-Meyer et al. 2007, Kooyman et al. 2007, Kooyman \& Ponganis 2016) and previous counts by W. Sladen and colleagues (Ainley et al. 1978) and others (Stonehouse 1964) beginning in 1960. Although the exact location of the colony has varied over the years, it is always dependent on fast ice between the Ross Ice Shelf (RIS) and Ross Island (Kooyman et al. 1971, Kooyman 1993). Since the beginning of this study (1996), the colony has primarily been located in the fast ice leads that form in the rifts in the RIS, but it occasionally has moved out of the cracks onto the ice between land and the shelf. The fast ice leads are typically very stable, offer shelter from the wind and retain fast ice longer than surrounding areas.

In 2018 , the unusually early breakup of the fast ice between Ross Island and the RIS resulted in a substantial loss of chicks. Although previous breeding failures have been documented at this colony, they were attributed to unusual conditions precipitated by the collision of a large iceberg (B15A) with the RIS that resulted in no available leads or stable fast ice (Kooyman et al. 2007, Kooyman \& Ponganis 2016). At a time when sea ice extent and concentration are in steep decline in many sectors of the polar ocean (Stammerjohn et al. 2012, Scott 2019), the importance of monitoring the status of ice-obligate species is heightened. Here, we extend the previously published (Barber-Meyer et al. 2007, Kooyman \& Ponganis 2016) time series of Cape 


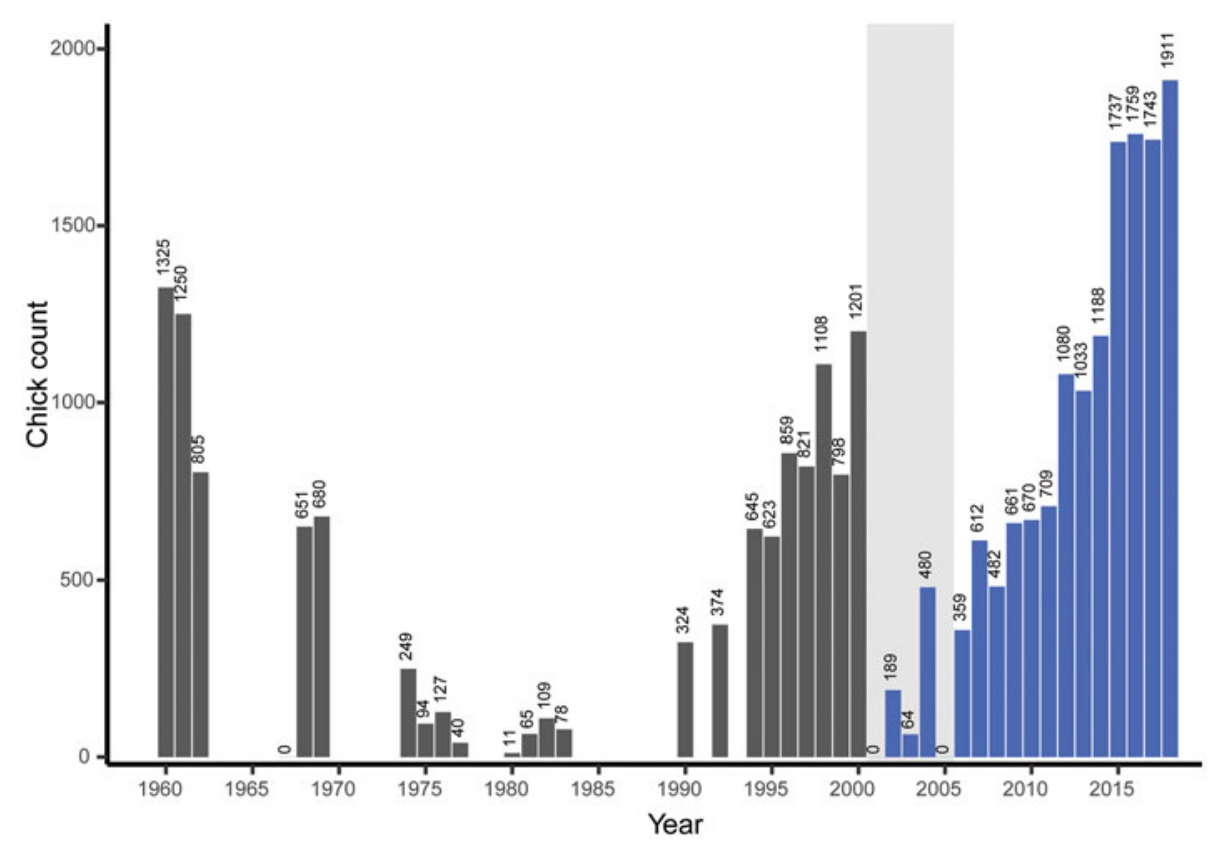

Fig. 1. Emperor penguin chick counts at Cape Crozier from 1960 through 2018. Dark grey bars are counts previously published by Kooyman \& Ponganis (2016) and blue bars are ground counts recorded by this study. The light grey shaded area indicates the years when the colony was impacted by mega-iceberg B15A.
Crozier emperor penguin chicks with data through 2018 and comment on the potential for climate-related changes to continue to affect this colony.

\section{Methods}

Emperor penguin chicks at the Cape Crozier colony $\left(77.455^{\circ} \mathrm{S}, 169.270^{\circ} \mathrm{E}\right)$ were counted annually in late November to early December, coinciding with the time of year when most adults were foraging at sea and chicks were generally alone at the colony but had not yet begun to leave (fledge) (Kooyman et al. 2007). Beginning in 2006, chicks were counted from photographs using either ArcMap (ESRI 2008) or open-source software (iTag) (https://sourceforge.net/projects/itagbiology). Photographs were taken either from the sea ice or from a higher land-based vantage point on Ross Island and overlaid manually in ArcMap, or stitched together using Adobe Photoshop ${ }^{\mathrm{TM}}$. Photographs in 2018 were counted by two independent observers and the average of the two counts was used. The average fledging date of chicks was estimated each year as the date after which more than $50 \%$ of the chicks had left the area of the colony. Twice-daily weather observations, including low temperature $\left({ }^{\circ} \mathrm{C}\right)$ and maximum wind gusts $\left(\mathrm{km} \mathrm{h}^{-1}\right)$, were recorded at a weather station established in a base camp $\sim 2.5 \mathrm{~km}$ from the emperor penguin colony. Mean daily low temperature and average maximum wind gusts were calculated over the first 2 weeks in December each year (the critical period just prior to chick fledging).

\section{Results}

The Cape Crozier emperor penguin colony was in a period of growth when the mega-iceberg B15A collided with the RIS early in 2001 (Kooyman et al. 2007). By March 2001, one end of B15A had settled between the RIS and Ross Island at Cape Crozier, breaking off the rifts where emperor penguins typically breed (Kooyman et al. 2007). The colony went from 1201 chicks in 2000 to 0 chicks in 2001. A small number of chicks were present in 2002-04, but a second complete failure occurred in 2005 (Kooyman et al. 2007). After the effects of the B15A iceberg dissipated in 2005, the Cape Crozier emperor colony experienced another period of rapid growth, sustained through to the present (Fig. 1). The positive trend in chick numbers was significant over this period (Pearson correlation $r=0.96, P<0.001$ ), with the colony adding an average of 96 chicks per year from 2006 to 2018. Annual growth rates averaged $17.7 \%$, but were punctuated periodically by large growth spurts every 2-3 years, including a 70\% increase from 2006 to 2007, a $37 \%$ increase from 2008 to 2009 , a $52 \%$ increase from 2011 to 2012 and a $46 \%$ increase from 2014 to 2015 (Fig. 2). Since the last growth spurt, chick numbers have remained high, and the 2018 count on 1 December $(n=1911)$ was the highest on record. The chick counts over the most recent 4 years were all higher than the previous high of 1325 recorded in 1960 (Fig. 1).

On 4 December 2018, 3 days after the high count, a majority of the fast ice between the RIS and Ross Island broke up during a storm (sustained winds of $75-93 \mathrm{~km} \mathrm{~h}^{-1}$ and gusts of up to $119 \mathrm{~km} \mathrm{~h}^{-1}$ recorded by the camp 


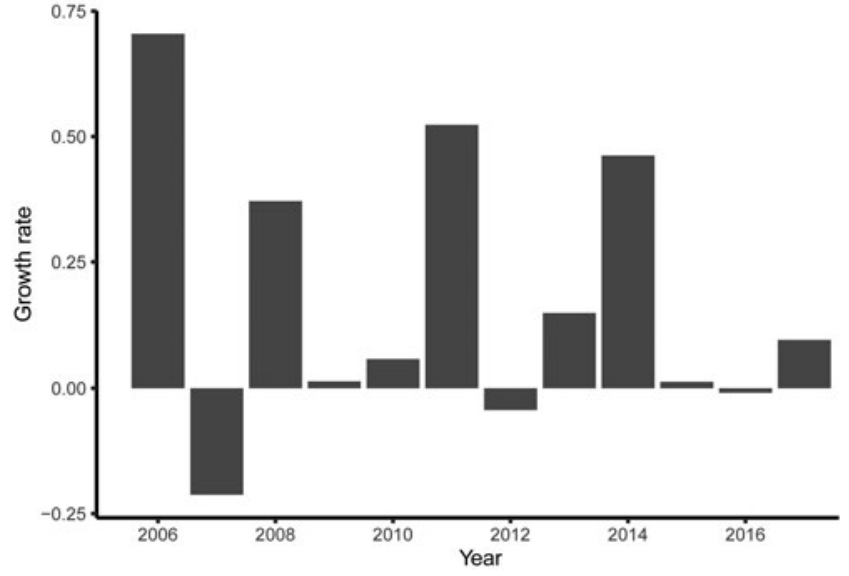

Fig. 2. Annual growth rate of chick counts during post-iceberg recovery, 2006-18.

weather station). Fast ice remained in the rifts in the ice shelf, but there was open water at the mouth of the rifts (Fig. 3). A day after the breakup, on 5 December, we noted several large groups of emperor penguin chicks that were on free-floating ice floes near the main colony (Fig. 3b). The subsequent photographs and count from 6 December revealed that 1051 chicks remained on the fast ice in the rift, but the floes, bearing 860 chicks $(45 \%$ of the chicks in the colony), were gone (Fig. 3c). The number of adults at or near the colony increased from 321 on 1 December to 814 on 6 December, with most adults gathered in groups with few or no chicks.

The average fledging date from 1996 to 2017 was 23 December, 19 days later than the breakup in 2018. The average overnight low temperature for the first 2 weeks in December 2018 was $-5.62^{\circ} \mathrm{C}, 0.52^{\circ} \mathrm{C}$ higher than the $2002-17$ average $\left(-6.14^{\circ} \mathrm{C}\right)$, but this was only the eighth warmest early December in the time series (Fig. 4a). No trend was evident in the early December low temperature, but there was a significant trend towards increasing maximum wind speed over the course of the study (Pearson correlation $r=0.48, P=0.049$ ) (Fig. 4b). The average daily maximum wind speed for early December 2018 was $54.4 \mathrm{~km} \mathrm{~h}^{-1}$, the third highest since 2002 (Fig. 4b).

\section{Discussion}

Emperor penguins rely heavily on seasonal fast ice, making them vulnerable to climate-driven changes in wind speed, fast ice extent and duration, as well as
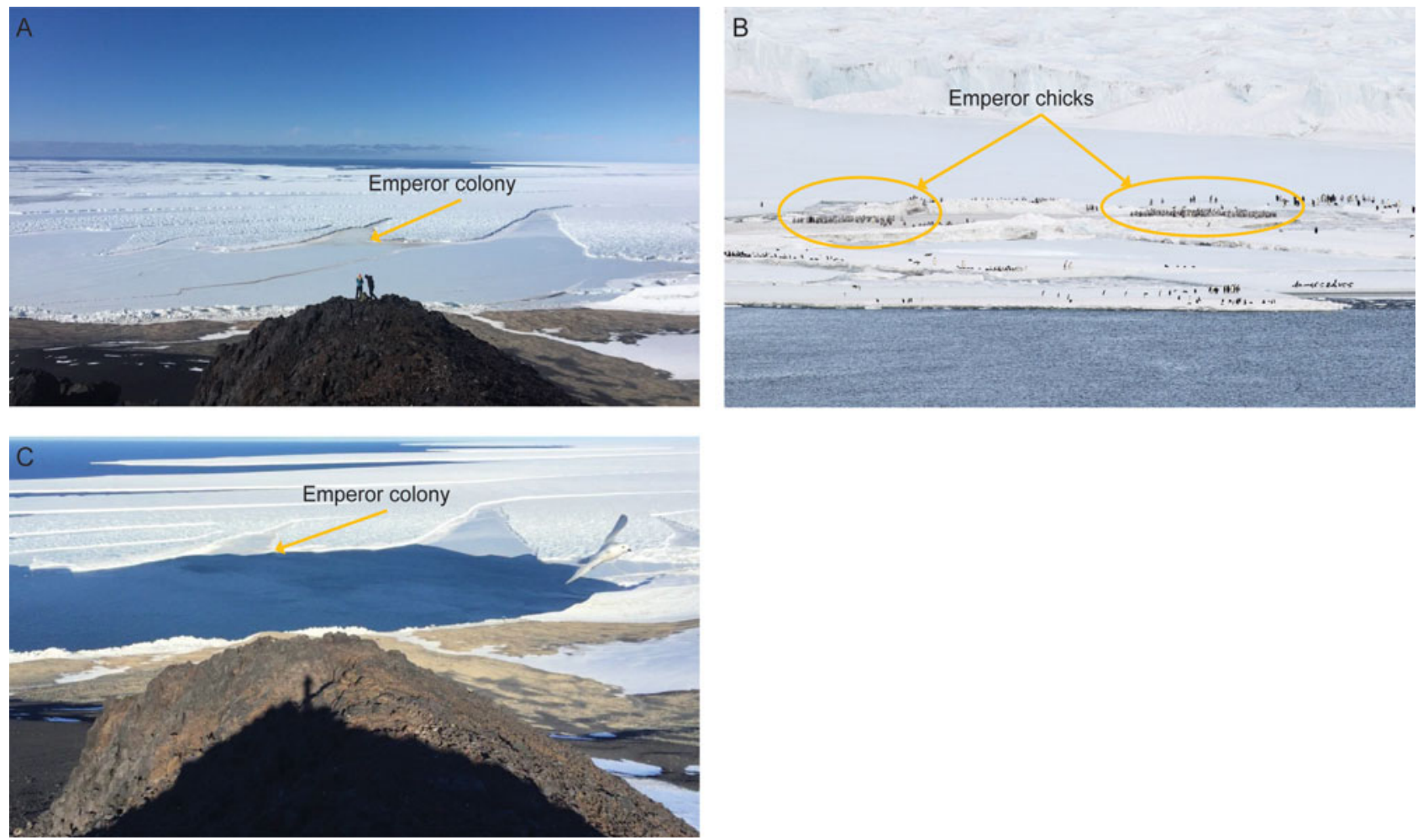

Fig. 3. a. Photograph showing fast ice between the Ross Ice Shelf and Ross Island and the location of the emperor penguin colony on 3 December 2018, the day before the fast ice broke up. b. Close-up photograph from 5 December 2018, the day after the storm, showing groups of emperor penguin chicks on two separate ice floes that subsequently disappeared. The Ross Ice Shelf is visible in the background. c. Photograph from 7 December 2018, 3 days after the storm, showing the extent of the fast ice breakout, and ice floes with emperor penguin chicks missing. Photographs by A.E. Schmidt and G. Ballard. 

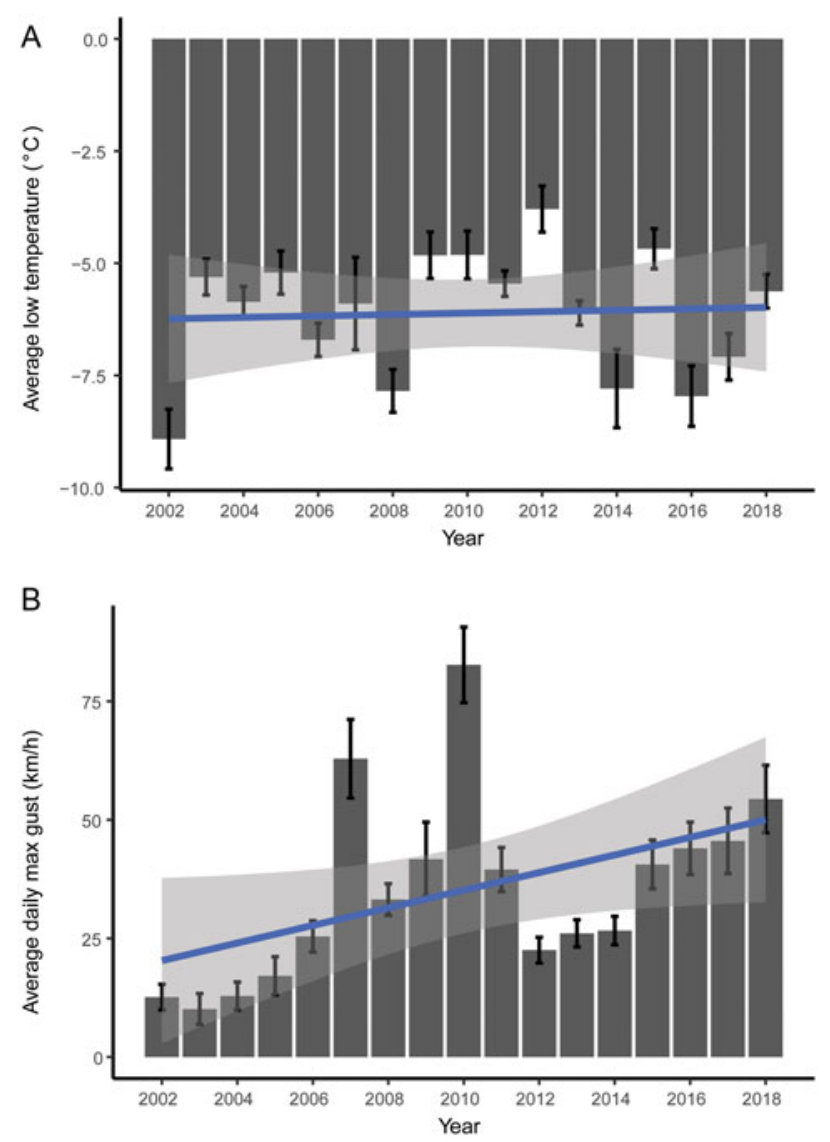

Fig. 4. a. Mean $24 \mathrm{~h}$ low temperature and b. average daily maximum wind gusts for the first 2 weeks of December, 2002-18, measured at a local weather station located $\sim 2.5 \mathrm{~km}$ from the emperor penguin colony. Trend lines represent linear regression with $95 \%$ confidence intervals.

unusual storm events (Fretwell \& Trathan 2019, Trathan et al. 2019). As chicks become more independent during the crèche stage, they begin to spread out and move towards the ice edge, where they may become particularly vulnerable to the storm events that lead to early fast ice breakup. Although periodic breeding failures or years of low breeding output at emperor colonies are not unheard of (Kooyman \& Ponganis 2016, Fretwell \& Trathan 2019), these events will likely become more frequent as the climate warms (Trathan et al. 2019). As the sea ice season and stability decline at lower latitudes, many emperor penguin colonies are predicted to decrease in size or disappear (Jenouvrier et al. 2009, Ainley et al. 2010, Trathan et al. 2011, 2019). The Ross Sea may become a refuge for this and other ice-obligate species as populations shift south (Jenouvrier et al. 2009, 2014, Ainley et al. 2010). Indeed, movement between colonies may be a regular and adaptive occurrence for the species that enables it to cope with variable fast ice over the long term (LaRue et al. 2015, Cristofari et al. 2016).
Cape Crozier is one of the southernmost emperor penguin colonies and also one of the smallest. It has displayed appreciable variability in chick counts over the decades, leading to the suggestion that the extreme periphery of the range also constitutes marginal habitat (Kooyman 1993, Barber-Meyer et al. 2007). The fast ice breakup at Cape Crozier in 2018 was the earliest observed in the past 20 years. While no similar events were observed over several years of observations during the 1960s-1980s (Ainley et al. 1978, Ainley personal observation, 1980-83), the colony at that time was much more exposed to ocean swells (Kooyman et al. 1971), which contribute to fast ice breakup (Kim et al. 2018). Its small size through that period may indicate a more frequent occurrence of low chick output, perhaps due to unstable ice. Since then, photographs from Kooyman et al. (1971), Kooyman (1993) and this study indicate that the edge of the RIS and the accompanying sheltering rifts have moved several kilometres further north (see also Keys et al. 1998). The advancing ice edge has led to an increase in the suitable fast ice habitat between the RIS and Ross Island, perhaps contributing to the recent observed growth at the Cape Crozier colony.

This recent growth may also be partly attributed to individuals moving to Cape Crozier from the nearby Beaufort Island colony $\left(\sim 65 \mathrm{~km}\right.$ north-west, $76.933^{\circ} \mathrm{S}$, $\left.166.833^{\circ} \mathrm{E}\right)$. Aerial surveys and satellite images suggest that the colony at Beaufort Island has declined in recent years, from a high of over 2000 chicks in the year 2000 (Kooyman \& Ponganis 2016) to no chicks present in 2011 (Kooyman \& Ponganis 2016) and 2016 (Ainley personal observation, 2016) and only 500 adults in 2018 (LaRue unpublished data, 2018). Early fast ice breakup at Beaufort Island in 2011 led to a catastrophic loss of chicks from that colony (Kooyman \& Ponganis 2016), and subsequent years of poor fast ice conditions may have encouraged penguins to move to Cape Crozier.

Although the chick loss from the early fast ice breakup may have been severe, we do not know that all of the chicks perished. Some of the chicks were already large and mostly feathered when they floated away, and they may have survived the forced early fledging. Depending on how far the floes drifted, their parents may have found them and provided one or two more meals. However, these chicks may have been separated from their parents 19 days ahead of the average fledging date for the colony, suggesting that many would not have been ready to be independent. The large increase in adults present near the colony after the breakup indicates that many adults were still intending to feed the chicks that went missing and waited around at the colony longer than usual when they could not locate them.

The increasing trend in early December wind speeds that we observed locally at Cape Crozier is consistent with model predictions (Ainley et al. 2010) for the 
region and may have been a contributing factor in the early breakup that year: higher wind speeds have been associated with the earlier breakup of fast ice in nearby McMurdo Sound, as well as other locations (Heil 2006, Massom et al. 2009, Kim et al. 2018).

The early fast ice breakup at Cape Crozier in 2018 coincided with a year of anomalously quick retreat of sea ice in the Ross Sea and Antarctica as a whole. Continent-wide, sea ice extent declined at a rate of $253000 \mathrm{~km}^{2}$ per day through December, the highest rate of loss in the satellite record (Scott 2019). Lower concentrations of pack ice may also contribute to earlier fast ice breakup by allowing more ocean swell to directly impact fast ice edges (Massom et al. 2018). Although the early breakup at Cape Crozier may just be an anomaly, it is concerning as it could indicate that the impacts of rising global temperatures have already reached the southern limit of the emperor penguin's range. This year offered a glimpse of a scenario that is likely to occur more often, and at more colonies, as global temperatures continue to rise.

\section{Acknowledgements}

We thank the many biologists who have participated in the chick counts, especially Viola Toniolo for her 5 year contribution and David Ainley, who also provided many useful comments on an earlier draft. We are grateful to Michelle LaRue and Gerry Kooyman who provided additional reviews. We also thank the US Antarctic Program for providing excellent logistical support every year. This is Point Blue Contribution 2264.

\section{Author contributions}

GB designed the study, AES analysed the data and both authors collected the data and wrote the paper.

\section{Financial support}

Funding for fieldwork and for preparing this manuscript was provided by the National Science Foundation Office of Polar Programs grants 0125608, 0439759, 0944141, 1543541 and 1543498.

\section{References}

Ainley, D.G., Wood, R.C. \& Sladen, W.J.L. 1978. Bird life at Cape Crozier, Ross Island. The Wilson Bulletin, 90, 492-510.

Ainley, D., Russell, J., Jenouvrier, S., Woehler, E., Lyver, P.O., Fraser, W.R. \& Kooyman, G.L. 2010. Antarctic penguin response to habitat change as Earth's troposphere reaches $2^{\circ} \mathrm{C}$ above preindustrial levels. Ecological Monographs, 80, 49-66.

Barber-Meyer, S.M., Kooyman, G.L. \& Ponganis, P.J. 2007. Trends in western Ross Sea emperor penguin chick abundances and their relationships to climate. Antarctic Science, 20, 10.1017/ s0954102007000673.
BARBRAUD, C. \& WeIMERSKIRCH, H. 2001. Emperor penguins and climate change. Nature, 411, 183-186.

Cristofari, R., Bertorelle, G., Ancel, A., Benazzo, A., Le Maho, Y., Ponganis, P.J., et al. 2016. Full circumpolar migration ensures evolutionary unity in the Emperor penguin. Nature Communications, 7, 11842.

ESRI 2008. ArcGIS desktop. Redlands, CA: Environmental Systems Research Institute.

Fretwell, P.T. \& Trathan, P.N. 2019. Emperors on thin ice: three years of breeding failure at Halley Bay. Antarctic Science, 31, 133-138.

Fretwell, P. T., LaRue, M.A., Morin, P., Kooyman, G.L., Wienecke, B., Ratcliffe, N., et al. 2012. An emperor penguin population estimate: the first global, synoptic survey of a species from space. PLoS One, 7, e33751.

HeIL, P. 2006. Atmospheric conditions and fast ice at Davis, East Antarctica: a case study. Journal of Geophysical Research, 111, $10.1029 / 2005 j \mathrm{jc} 002904$.

Jenouvrier, S., Caswell, H., Barbraud, C., Holland, M., Stroeve, J. \& Weimerskirch, H. 2009. Demographic models and IPCC climate projections predict the decline of an emperor penguin population. Proceedings of the National Academy of Sciences of the United States of America, 106, 1844-1847.

Jenouvrier, S., Holland, M., Stroeve, J., Barbraud, C., Weimerskirch, H., Serreze, M. \& Caswell, H. 2012. Effects of climate change on an emperor penguin population: analysis of coupled demographic and climate models. Global Change Biology, 18, 2756-2770.

Jenouvrier, S., Holland, M., Stroeve, J., Serreze, M., Barbraud, C., Weimerskirch, H. \& CAswell, H. 2014. Projected continent-wide declines of the emperor penguin under climate change. Nature Climate Change, 4, 715.

Keys, J.R., Stanley, S. \& Brigham, L.W. 1998. Continued northward expansion of the Ross Ice Shelf, Antarctica. Annals of Glaciology, 27, 93-98.

Kim, S., Saenz, B., Scanniello, J., Daly, K. \& Ainley, D. 2018. Local climatology of fast ice in McMurdo Sound, Antarctica. Antarctic Science, 30, 125-142.

Kooyman, G.L. 1993. Breeding habitats of emperor penguins in the western Ross Sea. Antarctic Science, 5, 10.1017/s0954102093000203.

Kooyman, G.L. \& Ponganis, P.J. 2016. Rise and fall of Ross Sea emperor penguin colony populations: 2000 to 2012. Antarctic Science, 29, 201-208.

Kooyman, G.L., Ainley, D.G., Ballard, G. \& Ponganis, P.J. 2007. Effects of giant icebergs on two emperor penguin colonies in the Ross Sea, Antarctica. Antarctic Science, 19, 10.1017/ s0954102007000065.

Kooyman, G. L., Drabek, C.M., Elsner, R., \& Campbell, W.B. 1971. Diving behavior of the emperor penguin, Aptenodytes forsteri. Auk, 88, 775-795.

LaRue, M.A., Kooyman, G., Lynch, H.J. \& Fretwell, P. 2015. Emigration in emperor penguins: implications for interpretation of long-term studies. Ecography, 38, 114-120.

Massom, R.A., Hill, K., Barbraud, C., Adams, N., Ancel, A., Emmerson, L. \& Pook, M.J. 2009. Fast ice distribution in Adélie Land, East Antarctica: interannual variability and implications for emperor penguins Aptenodytes forsteri. Marine Ecology Progress Series, 374, 243-257.

Massom, R.A., Scambos, T.A., Bennetts, L.G., Reid, P., SQuire, V.A. \& StammerJohn, S.E. 2018. Antarctic ice shelf disintegration triggered by sea ice loss and ocean swell. Nature, 558, 383-389.

Scoтt, M. 2019. A record-low start to the new year in Antarctica. National Snow and Ice Data Center: Arctic Sea Ice News and Analysis. Retrieved from http://nsidc.org/arcticseaicenews/2019/01/a-record-low-start-tothe-new-year-in-antarctica (accessed 5 February 2019).

Sсот, R.F. 1905. The voyage of the Discovery. London: Smith, Elder. 
Stammerjohn, S., Massom, R., Rind, D. \& Martinson, D. 2012. Regions of rapid sea ice change: an inter-hemispheric seasonal comparison. Geophysical Research Letters, 39, 10.1029/ 2012GL050874.

Stonehouse, B. 1964. Emperor penguins at Cape Crozier. Nature, 203, 849-851.

Trathan, P.N., Fretwell, P.T. \& Stonehouse, B. 2011. First recorded loss of an emperor penguin colony in the recent period of Antarctic regional warming: implications for other colonies. PLoS One, 6 e14738.

Trathan, P.N., Wienecke, B., Barbraud, C., Jenouvrier, S., Kooyman, G., Le BoHec, C., et al. 2019. The emperor penguin - vulnerable to projected rates of warming and sea ice loss. Biological Conservation, 10.1016/j.biocon.2019.108216.

WIENECKE, B. 2010. The history of the discovery of emperor penguin colonies. Polar Record, 46, 271-276. 